\title{
EFFECT OF SOWING METHODS ON THE YIELD AND YIELD COMPONENTS OF WHEAT UNDER TWO SEED RATES AT SULAIMANI REGION
}

\author{
F. F. Khurshid \\ lecturer
}

Dept. Agric. Mechan., Biotechn. and Crop Sci., Coll. Agric. Engi. Sci. University Sulaimani, Iraq

Fawzy.Khurshid@univsul.edu.iq

\section{ABSTRACT}

This experiment was implemented in the College of Agricultural Engineering Sciences fields in Bakrajo-Sulaymaniyah in two consecutive cropping seasons, 2017-2018 and 2018-2019. Two seeding rates were applied with three seeding methods, seed drill, conventional scattering pattern by centrifugal seeds spreader, and an un familiar pattern in the region, which is the overlapping pattern of grain spreading lines by the distributor. the coefficient of variance (\% $\mathrm{CV}$ ) for seeds had the best value in comparison to overlap spreading, which in turn was better than conventional scattering was 1.1, 8.2 and 47.2 for seed rate of $200 \mathrm{~kg} \mathrm{ha}^{-1}$ and 1.7, 7.6, and 44.8 for seed rate of $160 \mathrm{~kg} \mathrm{ha}^{-1}$ respectively. The seeding rate $200 \mathrm{~kg}$ ha-1 was significantly recorded higher averages for most of the studied traits. The sowing patterns had significantly superior to the overlapped grain spreading lines when it recorded $106.23 \mathrm{~cm}$ plant high, 341.47 spikes $\mathrm{m}^{-2}, 43.1$ grains spike ${ }^{-1}, 38.7 \mathrm{~g}$ thousand grains weight, $3623.74 \mathrm{~kg} \mathrm{ha}^{-1}, 11379.03$ $\mathrm{kg} \mathrm{ha}^{-1}$ and 0.32 harvest index. The overlapped spreading mode also significantly superior to the conventional mode of prose.

Key word: sowing patterns, seed drill, overlap spreading, spikes $\mathbf{m}^{-2}$.

$$
\text { تاثير طرائق الزراعة على حاصل الحنطة ومكوناته تحت معدلين للبذار في منطقة السليمانية }
$$

قسم التقتيات الحياتية و علوم المحاصيل, كلية علوم الهندسة الزراعية, جامعة السليمانية المكنتة الزراعية،

تم تنفيذ التجرية في حقول كلية علوم الهندة الزراعية في بكرجو- السليمانية في موسمين زراعيين متتالين 2017-2018

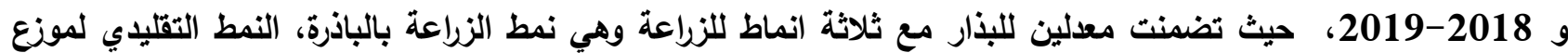
الحبوب بالطرد المركزى مع نمط ثالث غير متبع في الاقليم وهو النمط المتذاخل لخطوط نثر الحبوب للموزعة. اعطى نمط الزراعة بالباذرة افضل نتيجة لصفة معامل التباين (CV \%) لتجانس توزيع البذور مقارنة بالنمط المتداخل والذي بدوره كانت

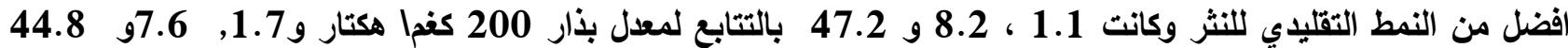
بالتتابع ايضا ولكن عند معدل بذار 160كفما هكتار. سجل معدل البذار 200 كفما هكتار تفوق معنوي لمتوسطات اغلب الصفات المدروسة. كما نفوقت الزراعة بالباذرة على النمط المتداخل لخطوط النثر معنويا بنسجيل 106.23سم ارتفاع للنيات، 341.47 سنبلة لكل م2، 43.1 حبة لكل سنبلة، 38.7 غم وزن الالف حبة، 3623.74 كفما هكتار، 11379.03 كفما هكتار و0.32 دليل حصاد، كما تفوق نمط النثر المتذاخل على النثر التقليدي في تسجيل متوسطات افضل لاغلب الصفات المدروسة. الكلمات المفتاحية: انماط الزراعة, باذرة الحبوب, النثر المتداخل، عدد السنابل في المتر المريع. 


\section{INTRODUCTION}

Wheat (Triticum aestivum $L$ ) ranks first in cereal production in the world. It is considered the most important crop used as a staple food by about a third of the world's population (15). Where different food forms can be produced from this crop, wheat consumption is expected to double by 2050 as the population increases and the demand for its products increases (24), especially in developing countries. Where the trend is towards increasing the production per unit area while maintaining its quality with sufficient care (33). And do not forget its high quality in its inclusion as an important factor in the composition of feed in feeding livestock and poultry. The rate of seeds and sowing manners are two of the most influential factors in increasing production per unit area. In which increasing sowing rates increases the number of plants per unit area, which means higher yields. This relationship is real because many plants mean increased competition between them, which leads to the failure of many plants to reach the typical size of the harvest; in this case, the result, is the opposite, (20). The low yield is attributed to many factors viz. sowing patterns, seed rate, and varietal potentiality. Yield is the function of many components when that yield relating components have been modified and observed direct influence on the production enhancement viz. optimum seed rate, plant density, climatic condition, soil, sowing time and varieties (21). The competition between individuals and populations can be controlled indeterminately through optimum cultivation intensity, by establishing a suitable population pattern, (34). Seeding rates below optimum may reduce yield potential, while excessive seeding rates increase lodging, create a more enormous potential for disease, and increase seed costs. The optimum planting should be calibrated for seed drill is to put 30 to 35 live seeds per square foot $\left(3,800,000\right.$ seeds. ha $\left.{ }^{-1}\right)$ to obtain at least 25 plants per square foot. The rotary seed spreader, the rates should be increases by 30 to 35 percent over drilled seeding rates (45 to 47 seeds per square foot) In order to compensate for the shortage in the number of seeds necessary for proper emergence per unit area. The shortage in the number of plants unit area required is due to the irregular establishment of the seedbed in addition to the unequal distribution of seeds on the soil surface (13). The higher seed rate leads to an increase in water consumption prior to synthesis, lead to greater plant height grains and grains in the spike (10 and 25). When the seeding rate is increased to a certain extent, it leads to an increase in spikes per square meter, biological yield, and thus crop yield (1). In a study on the effect of seed rates of $60,80,100$ and $120 \mathrm{~kg} \mathrm{ha}^{-1}$ on the regulation of tillering in wheat and its relationship to grain yield and its components, the results indicated that the seeding rate of 80 $\mathrm{kg} \mathrm{ha}{ }^{-1}$ was significantly superior giving the highest average number of spikes $m^{-2}$ by 363 spikes and a grain yield of 4.775 tons $\mathrm{h}^{-1}$ compared to other seed rates (18). Usually standard deviation of plant spacing (SD) and coefficient of variation (CV) are used to represent the seeding equilibrium. Resulting in good germination quality, the yield will directly depend on the quality of sowing and plant organization per unit of surface area, (30). The Coefficient of Variation (CV) is an indicator measurement of how uniformity the granular distributes; Better spreaders should have both a low CV less than $5 \%$ and a good basic spread pattern - and these should be verified by an independent test conditions in test halls. However, in the field, values up to $15 \%$ are acceptable, but once the $\mathrm{CV}$ goes above $20 \%$ a crop and financial loss will happen (11). The distribution pattern of the scattered seeds over the soil is not sufficient even after conducting all the modifications that can be obtained, based on the numerous recommendations of many books and researchers to solve the problem of nonhomogeneity by making the application rate for half and covering the field twice in perpendicular direction (7). The sowing pattern has a massive impact on the variation of winter wheat seed rates. Also, a common drilled seed rate of $120 \mathrm{~kg} \mathrm{ha}^{-1}$ is used for all the varieties, still farmers use too high seeding rate, and sometimes they even use twice amount than the recommended in order to control weeds, compensate the wasted amount by the birds and higher yield expectation, and, they observed that with increasing the seeding application rates, the total production was 
increased (3). It is important to notice that seed drill planter allowed a saving in wheat seeds of $26 \%$ as compared to the seed spreader method (12). In the field, seed broadcasters are used for granular (fertilizers and seeds) to increase the expected yield and crop quality and save time, energy, and cost requirements. (6 and 9). Broadcasting not only requires a highest seed rate but also results in a lower number of plants, as drilling sowing method, which is recommended due to the uniform distribution of seeds and sowing to the required depth, which usually results in higher germination and uniform seed horizontally and vertically distribution (25). It is necessary to follow the modern technique of broadcasting by scattering the granules by two passes across the field; in this case, half of the seeding rate must be applied for each pass as recommended by many researchers and specialists (22). This study was aimed to determine the best seeding pattern and seeding rate applied to introduce highest wheat yield in Sulaimani region.

\section{MATERIALS AND METHODS}

The field experiment was conducted at Bakrajo Experimental fields of the College of

Table 1. Agro-climatic conditions at the Bakrajo Experimental Station during cropping season 2017-2018 and 2018-2019

\begin{tabular}{|ccccccccccc|}
\hline \multirow{2}{*}{ Season } & & Oct. & Nov. & Dec. & \multicolumn{2}{c}{ Months } \\
Jan. & Feb. & Mar. & Apr. & May & Total \\
Precipitation $(\mathbf{m m})$
\end{tabular}

The study was applied using Randomized completely Block Design in split plot arrangement using three replications, each was consisting of two factors: the first factor represented two main plots, net treated size of (48x 40) $\mathrm{m}$ for each, which were for seeding rates: $200 \mathrm{~kg} \mathrm{ha}^{-1}$ as (S1) and $160 \mathrm{~kg} \mathrm{ha}^{-1}$ as (S2), the second factor placed as sub plots which were for seeding method: seed drill as (SD), spinning disc seed broadcaster with conventional spreading pattern as (CP) and spinning disc seed broadcaster with overlapped spreading pattern as (OP). Each plot size was $16 \mathrm{~m}$ width $\times 40 \mathrm{~m}$ long. For both seasons, the land was plowed by Moldboard
Agricultural Engineering Sciences, Sulaimani University, located at the southwest of Sulaimani city, Iraq- Kurdistan region, during November of 2017 and 2018. Two fallow land were selected for each cultivating season, which previously plowed in spring. The experiment was conducted when the soil moisture was approximately $18 \%$ with Silty Clay texture and $\mathrm{pH}$ of 7.44 . The prevailing climate for this location is rainy with cloudy winters, rainy springs, hot and dry summers, the information on agro-climatic conditions is given in Table 1. Adana wheat variety was sown in the experiment. After taking into consideration the germination rate of wheat 90 $\%$ seeds, the amount of fertilizer added per hectare and the recommendations of many researches due to articles in particular (13), regarding the optimal seed rate for unit of area, the seed rates of 160 and $200 \mathrm{~kg} \mathrm{ha}^{-1}$ were selected for sown by each of seed drill and grain spreader. It should be noted that these rates are the same rate as followed by most farmers in Iraq - Kurdistan region.

and harrowed during the perform of the experiment. The plots which sown by the spreader, the seeds were covered with a tinetype harrow till to $10 \mathrm{~cm}$ deep.

\section{Calibration}

The calibration of the machine ensures the seeds can be set in a place which can give the required number of granules above the soil surface. The calibration was started by carrying out the following steps mentioned by (16). The coefficient of variation for the seeds placed in the soil by seed drill also was found by the same equation used for Broadcaster machine. The process was started by adopting the same method followed by other researchers 
(2). A plastic strip of $20 \mathrm{~m}$ by $1.5 \mathrm{~m}$ was elongated on the land. A layer of fine sand of $50 \mathrm{~mm}$ thickness was placed out on the plastic strip. The seed drill run and seeds were drilled over the sand layer at selected forward speed for the study. Several meter squares were randomly selected using a wooden frame. A sieve was used for separate the planted seeds in the chosen randomly area from the sands. The test was replicated three times and the average was taken to compute the coefficient of uniformity of seed distribution.

\section{Calibration of seed broadcaster}

The calibration was carried out as followed by others (17 and 23). The machine was operated over a level floor area on the selected speed and feed rate settings for each seed rate. During the run, seeds were collected in a series of trays placed at perpendicular angles to the line of tractor travel. 20 collectors of $1.0 \times 1.0$ $\mathrm{m}$ (each had partitions barriers) spaced in 0.5 $\mathrm{m}$ (for tractor tire pass) were used. Following each test, the contents of each tray were weighed until the required seed rate was obtained. Table (2) and following histograms in Fig.1 and Fig.2 were drawn to show the seeds distribution pattern. After the calibration processes was completed at the required seed rates, the wheat grains were grown as the conventional manner which followed by the farmers. As Fig.1 and Fig. 2 shows the distribution of wheat granules is uneven over the soil surface and the seed distribution pattern tends to be like a bell-shaped as confirmed by other (32) that, Intensive seeds are divided into distributed path center, while utilization rates decrease as we move far away from the prose center. In order to distribute the seeds uniformly on the soil surface, it is necessary to follow the modern technique by broadcast granules in two passes across the field, and that occur completely by (13 and 22). Therefore, other calibrations were made for both seed rate 80 and $100 \mathrm{~kg}$ as the same manner as mentioned previously for 160 and $200 \mathrm{Kg} \mathrm{ha}^{-1}$. During the calibration process, the wind velocity was very low and almost negligible and had no effect on the granular distribution pattern. After the calibration process was completed, the wheat seeds were grown in the field by following half-width method and half rate application (a right-onright) and (a left -on-left) overlap pattern. Fig.3 explains the modern technique pattern for sowing wheat seeds.

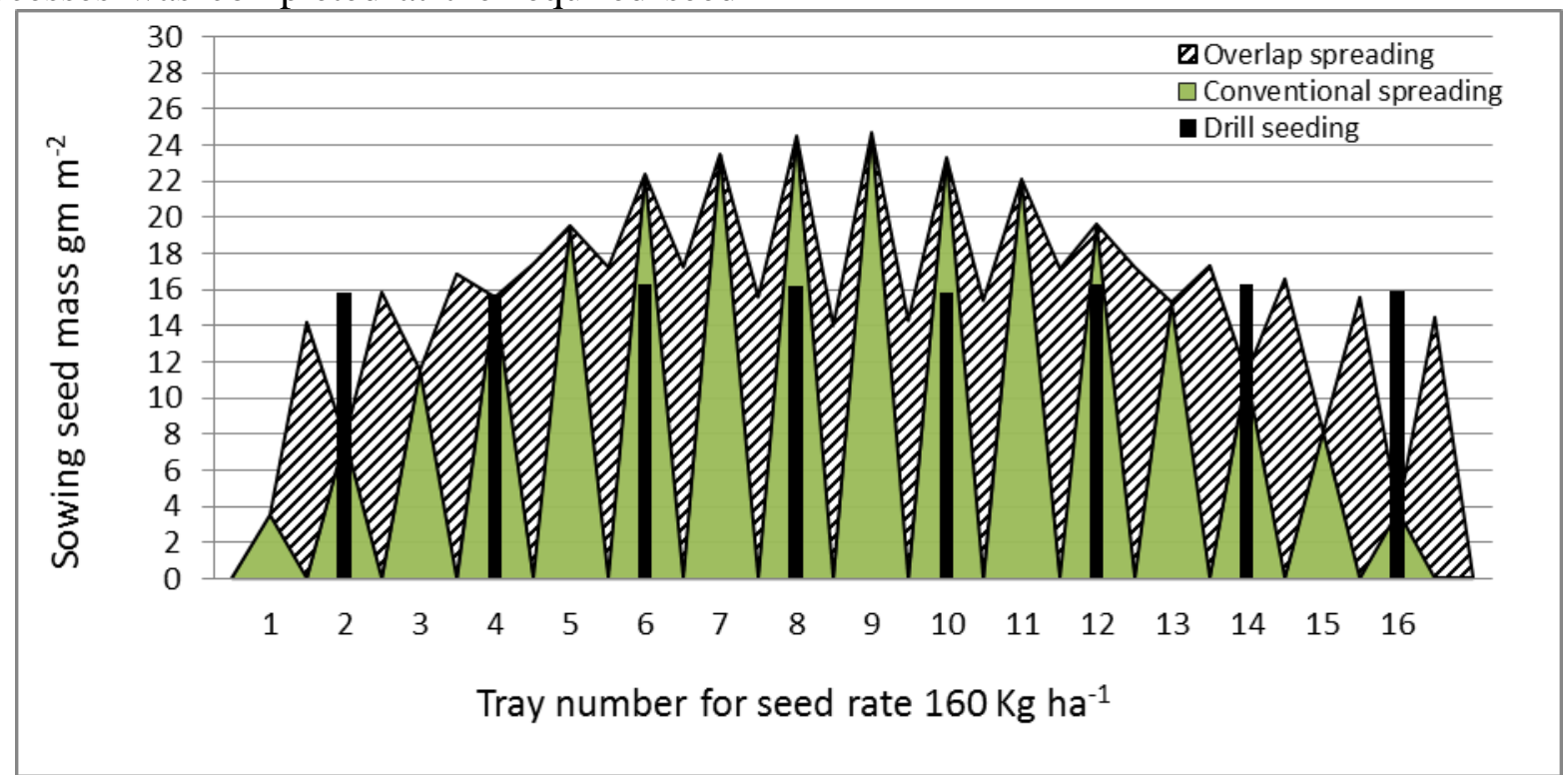

Figure1. Seed distribution pattern for both conventional and overlapped spreading after calibration of the seed broadcaster on seeding rate $160 \mathrm{~kg} \mathrm{ha}^{-1}$ 

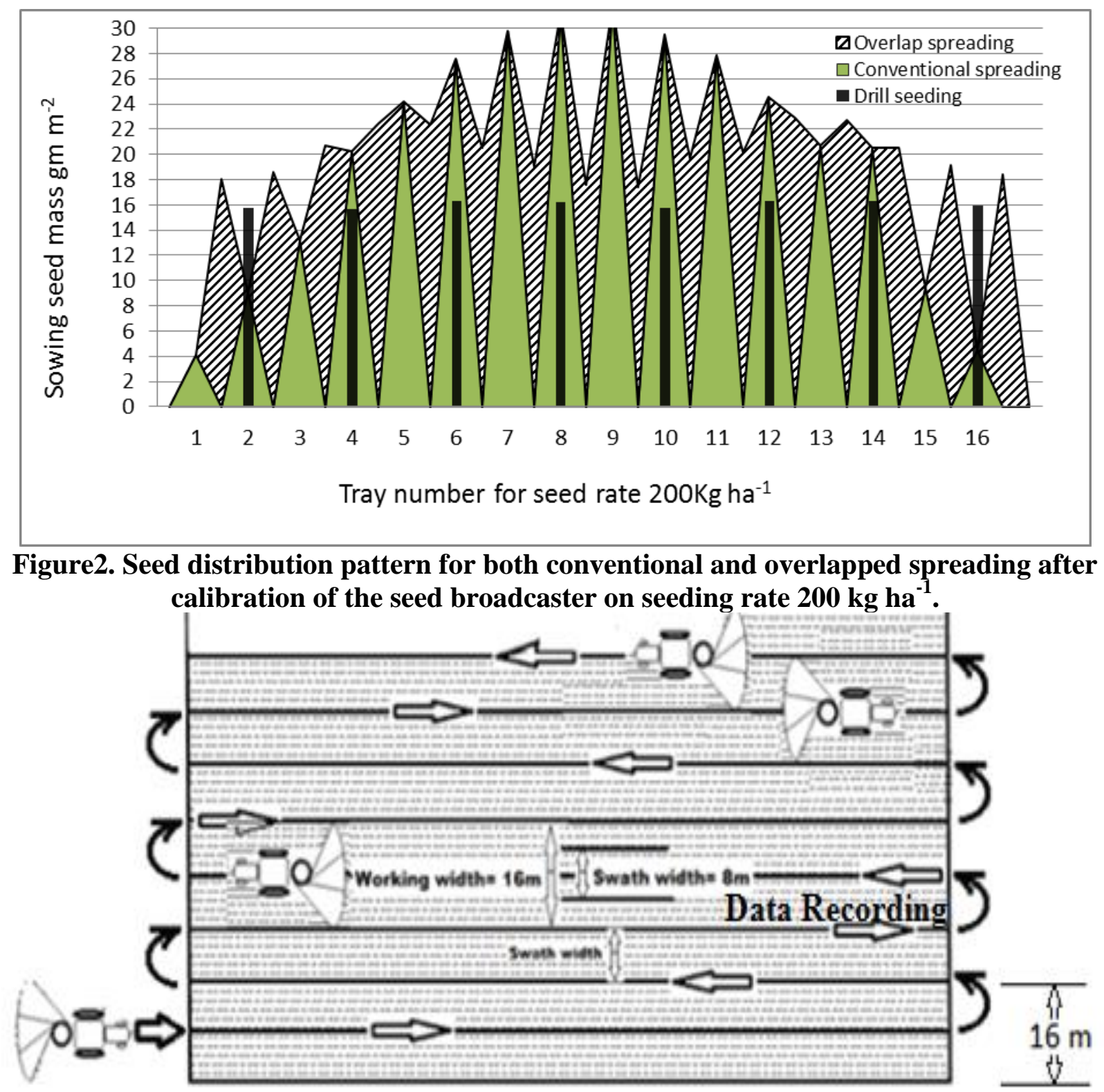

Figure3. Spreading sowing for wheat seeds by applying the overlapped mode (a right-onright) and (a left -on-left).

\section{Coefficient of variation (C.V.)}

Coefficient of variation is a relative measure of dispersion that gives the standard deviation as a percentage of the mean value; the following formula was used to calculate the C.V as (4) mentioned:

$\mathrm{CV} \%=(100 \times \mathrm{Sd}) / \overline{\mathrm{x}}$

$$
s d=\sqrt{\frac{1}{n} \sum_{i=1}^{n}(x i-\bar{x})^{2}}
$$

Where;

$\mathrm{CV}=$ Coefficient of variation

$\mathrm{Sd}=$ Standard division

$\mathrm{n}=$ Number of observations

$\mathrm{xi}=$ Value of an individual observation

$\mathrm{x}=$ Mean value of all observations
Four samples were taken randomly from each plot, the area of each sample was one meter square, and subjected for recording data using standard methods. Following treats were recorded:

$\mathrm{x}=$ Mean value of all observations

2- Plant height $(\mathrm{cm})$

3- Numbers of spikes $\mathrm{m}^{-2}$

4- Numbers of grains spike ${ }^{-1}$

5- 1000- grains weight (g)

6- Grain yield $\left(\mathrm{Kg} \mathrm{ha}^{-1}\right)$

7- Biological yield $\left(\mathrm{t} \mathrm{ha}^{-1}\right)$

8- Harvest Index (\%).

The data were statistically analyzed and then the averages were compared by Duncan's multiple ranges for a test under the 5\% probability level 


\section{RESULTS AND DISCSSION}

\section{Coefficient of variation (C.V.)}

Results in Table 2 show the coefficient of variance (C.V) for both seeding rates $200 \mathrm{Kg}$ $\mathrm{ha}^{-1}$ and $160 \mathrm{Kg} \mathrm{ha}{ }^{-1}$ which indicate that seeding by conventional distribution results high value of $48.4 \%$ and $46.8 \%$ CV respectively, that mean, the homogeneity of distribution was very bad compared to the overlapped pattern of grain distribution when gave $9.2 \%$ and $7.8 \%$ for the two seed rates respectively. As known, the lower the coefficient of variation, the better the distribution. The reason of the variance could be due to in centrifuge type of spreader, the grain is scattered by the rotating disc after falling from the control gate of the exit amount of the granules. The spinning disc results a centrifugal force. By means of radial feathers on the spinning disc, the centrifugal force pushes those falling seeds to out in all directions and far away from the center of the rotation. In fact, the plate barrier which place in the back part of broadcaster (tractor side) prevents the seeds from being distributed, that a small percentage of the grain bounce towards the rotate disc to dispersed again, while, most of these grains, fall on the ground in places near to the center of the prose disc which causing an increase in the number of grains $\mathrm{m}^{-}$ 2 compared to places far from the center. This fact is consistent with what was confirmed by (23). Results in Table 3 show that the weather conditions did not significantly affect most studied characters except on grain yield. The second cropping season gave highest production by $3209.9 \mathrm{~kg} \mathrm{ha}^{-1}$ than the first cropping season $3003.33 \mathrm{Kg} \mathrm{ha}^{-1}$. The reason for these results might be due to the differences in the precipitation percent between the two-cultivation season as it shows in Table 1, since the abundance of water available to the plant in the soil by precipitation was higher in the second year $1215.6 \mathrm{~mm}$, which did not cost the plant more effort for absorption for growth and make more grains compared to the second cultivation season $755.8 \mathrm{~mm}$. This is in agreement with Twizerimana et al. (31) concluded that the planting season did not have a significant effect on the high intentions nor on the number of grains per spike but it led to a significant increase in the grain yield.

Table 2. Coefficient of variance (C.V) for seeding uniformity for the samples of seeds collected for each of seed drill, overlapping prose and conventional spreading

\begin{tabular}{|c|c|c|c|c|c|c|c|}
\hline \multirow{2}{*}{$\begin{array}{l}\text { Scattering } \\
\text { side }\end{array}$} & \multirow{2}{*}{$\begin{array}{l}\text { Collecting } \\
\text { trays number }\end{array}$} & \multicolumn{3}{|c|}{$\begin{array}{l}\text { Sowing method at a seeding rate } \\
200 \mathrm{~kg} \mathrm{ha}^{-1} \text { in }\left(\mathrm{g} \mathrm{m}^{-2}\right)\end{array}$} & \multicolumn{3}{|c|}{$\begin{array}{l}\text { Sowing method at a seeding rate } \\
160 \mathrm{~kg} \mathrm{ha}^{-1} \text { in }\left(\mathrm{g} \mathrm{m}^{-2}\right)\end{array}$} \\
\hline & & SD* & O & C & SD & O & C \\
\hline \multirow{9}{*}{ Right } & 1 & $\begin{array}{ll}19.8 \\
\end{array}$ & 18.1 & 4.1 & 15.8 & 14.2 & 3.5 \\
\hline & 2 & & 18.6 & 9.1 & & 15.8 & 7.7 \\
\hline & 3 & 20.2 & 20.7 & 13.2 & 15.7 & 16.9 & 11.5 \\
\hline & 4 & & 22.5 & 20.3 & & 17.4 & 15.6 \\
\hline & 5 & 20.1 & 22.4 & 24.2 & 16.3 & 17.2 & 19.5 \\
\hline & 6 & & 20.5 & 27.6 & & 17.2 & 22.4 \\
\hline & 7 & 19.7 & 19.1 & 29.8 & 16.2 & 15.6 & 23.5 \\
\hline & 8 & & 17.6 & 31.3 & & 14.0 & 24.5 \\
\hline & 9 & 19.9 & 17.4 & 31.9 & 15.8 & 14.3 & 24.7 \\
\hline \multirow{7}{*}{ Left } & 10 & & 19.7 & 29.5 & & 15.4 & 23.3 \\
\hline & 11 & 20.3 & 20.2 & 27.9 & 16.3 & 17.1 & 22.1 \\
\hline & 12 & & 22.9 & 24.6 & & 17.2 & 19.6 \\
\hline & 13 & 20.2 & 20.7 & 20.7 & 16.3 & 17.3 & 15.3 \\
\hline & 14 & & 20.5 & 12.9 & & 16.6 & 11.3 \\
\hline & 15 & 19.8 & 19.2 & 9.4 & 15.9 & 15.6 & 8.1 \\
\hline & 16 & & 18.8 & 4.5 & & 14.5 & 4.5 \\
\hline Coefficient & riance CV\% & 1.1 & 8.2 & 47.2 & 1.7 & 7.6 & 44.8 \\
\hline
\end{tabular}

Table 3. Effect of cropping season on wheat grain yield and its components

\begin{tabular}{|c|c|c|c|c|c|c|c|}
\hline Season & $\begin{array}{c}\text { Plant } \\
\text { height } \\
(\mathrm{cm})\end{array}$ & $\begin{array}{c}\text { Spike } \\
\text { number } \mathbf{m}^{-2}\end{array}$ & $\begin{array}{c}\text { Grain } \\
\text { number } \\
\text { spike }^{-1}\end{array}$ & $\begin{array}{l}\text { Thousand } \\
\text { kernel weight } \\
\text { (g) }\end{array}$ & $\begin{array}{c}\text { Grain } \\
\text { yield (kg } \\
\left.\text { ha }^{-1}\right)\end{array}$ & $\begin{array}{l}\text { Biological yield } \\
\left(\mathrm{kg} \mathrm{ha}^{-1}\right)\end{array}$ & $\begin{array}{c}\text { Harvest } \\
\text { index }\end{array}$ \\
\hline $2017-2018$ & 95.46 a & 309.69 a & $39.46 \mathrm{a}$ & $39.98 \mathrm{a}$ & $3003.33 \mathrm{~b}$ & 10190.77 a & $0.3 \mathrm{a}$ \\
\hline 2018-2019 & $97.41 \mathrm{a}$ & 315.78 a & 39.95 a & $40.07 a$ & 3209.9 a & 10219.24 a & $0.31 \mathrm{a}$ \\
\hline
\end{tabular}


The results showed in Table 4 illustrate the effect of the seeding rate on the yield of wheat grains and its components, where the seed rate of $200 \mathrm{~kg}$ hectare had a significant effect on each of the spike number $\mathrm{m}^{-2}$, the number of seeds per spike, the grain yield and the biological yield by giving the highest values by $320.62,40.87,3300.43 \mathrm{~kg} \mathrm{ha}^{-1}$ and 10880 $\mathrm{kg} \mathrm{ha}{ }^{-1}$ respectively, compared to the results obtained from the application of seed rate 160 $\mathrm{kg} \mathrm{ha}^{-1}$. While the plant height, the weight of a thousand grains and the harvest index were not affected by the seed rate when the application amount decreased from $200 \mathrm{~kg}$ to $160 \mathrm{~kg} \mathrm{ha}^{-1}$. The reason for the significant differences could be due to the increases in competition between plants resulting from the high seed rates leads to a decrease in the number of tillers that carry spikes per plant and not the total number of spikes unit area ${ }^{-1}$ within some ranges of plant density. It seems clear that the increase in the number of main plants per unit area resulting from the increases in the seeding rate overcame the decrease in the number of stems produced by one plant due to the increases in seed density (5 and 29). Also, using low seeding rates will not produce the required number of plants in the field, and thus it will not be able to use light, water and nutrients with high efficiency, which results in less yield (27).

Table 4. Effect of seed rate on wheat grain yield and its components

\begin{tabular}{|c|c|c|c|c|c|c|c|}
\hline $\begin{array}{c}\text { Seed rate } \\
\text { Kg ha }^{-1}\end{array}$ & $\begin{array}{c}\text { Plant } \\
\text { height } \\
(\mathbf{c m})\end{array}$ & $\begin{array}{c}\text { Spike } \\
\text { number } \mathbf{m}^{-2}\end{array}$ & $\begin{array}{c}\text { Grain } \\
\text { number } \\
\text { spike }^{-1}\end{array}$ & $\begin{array}{l}\text { Thousand } \\
\text { kernel } \\
\text { weight (g) }\end{array}$ & $\begin{array}{l}\text { Grain yield } \\
\left(\mathrm{kg} \mathrm{ha}^{-1}\right)\end{array}$ & $\begin{array}{c}\text { Biological } \\
\text { yield } \\
\left(\mathrm{kg} \mathrm{ha}^{-1}\right)\end{array}$ & $\begin{array}{c}\text { Harvest } \\
\text { index }\end{array}$ \\
\hline 200 (S1) & $97.27 \mathrm{a}$ & 320.62 a & $40.87 a$ & $40.28 \mathrm{a}$ & 3300.43 a & 10880.96 a & $0.3 \mathrm{a}$ \\
\hline 160 (S2) & 95.59 a & 304.85 b & $38.55 \mathrm{~b}$ & 39.77 a & $2912.81 \mathrm{~b}$ & 9529.05 b & 0.31 a \\
\hline
\end{tabular}

Data in Table 5, shows that there are clear significant differences for the effect of seeding type on most of the studied traits, where sowing pattern with seed drill recorded the highest values when had $106.23 \mathrm{~cm}, 341.47$, $43.1,3623.74 \mathrm{~kg} \mathrm{ha}^{-1}, 11379.03 \mathrm{~kg} \mathrm{ha}^{-1}$ and 0.32 for plant height, spike numbers per $\mathrm{m}^{2}$, grain numbers spike ${ }^{-1}$, grain yield, biological yield and harvest index respectively. While the treatment of sowing by conventional seed spreading by grain distributor machine recorded lowest values which were $86.56 \mathrm{~cm}$, $285.3,36.17,2663.16 \mathrm{~kg} \mathrm{ha}^{-1}, 11379.03 \mathrm{~kg} \mathrm{ha}^{-}$ 1 and 0.31 for the studied traits respectively except for thousand kernel weight and harvest index, where the lowest mean value was 40.06 $\mathrm{g}$ and 0.29 respectively, when the overlapped spreading pattern of seeds was applied. These differences between the treatments average are due to the variance distribution of seeds over the surface of the soil, where the seeding by seed drill left the seeds more homogeneous than the application of the overlapped method of prose lines of the seed distributor, which in turn, the homogeneity distribution of the grains is better than the seed dispersal by the conventional method, the practice of farmers, as explained in the Table 2. The irregular distribution of seeds makes plant competition for energy sources differ from place to another in the treated area, which ultimately negatively affects the growth of the plant (25).

Table 5. Effect of seeding pattern on wheat grain yield and its components

\begin{tabular}{|c|c|c|c|c|c|c|c|}
\hline $\begin{array}{l}\text { Seed rate } \\
\mathrm{Kg} \mathrm{ha}^{-1}\end{array}$ & $\begin{array}{c}\text { Plant } \\
\text { height } \\
(\mathrm{cm}) \\
\end{array}$ & $\begin{array}{c}\text { Spike } \\
\text { number } \mathbf{m}^{-2}\end{array}$ & $\begin{array}{c}\text { Grain } \\
\text { number } \\
\text { spike }^{-1}\end{array}$ & $\begin{array}{l}\text { Thousand } \\
\text { kernel } \\
\text { weight (g) }\end{array}$ & $\begin{array}{l}\text { Grain yield } \\
\quad\left(\mathrm{kg} \mathrm{ha}^{-1}\right)\end{array}$ & $\begin{array}{c}\text { Biological } \\
\text { yield } \\
\left(\mathrm{kg} \mathrm{ha}^{-1}\right)\end{array}$ & $\begin{array}{c}\text { Harvest } \\
\text { index }\end{array}$ \\
\hline SD & 106.23 a & 341.47 a & $43.1 \mathrm{a}$ & $38.7 \mathrm{a}$ & 3623.74 a & 11379.03 a & $0.32 \mathrm{a}$ \\
\hline $\mathbf{C P}$ & $86.56 \mathrm{c}$ & $285.3 \mathrm{c}$ & $36.17 \mathrm{c}$ & $41.32 \mathrm{c}$ & $2663.16 \mathrm{c}$ & $8725.34 \mathrm{c}$ & $0.31 \mathrm{c}$ \\
\hline OP & $96.50 \mathrm{~b}$ & $311.45 \mathrm{~b}$ & 39.85 b & $40.06 \mathrm{~b}$ & $3032.96 \mathrm{~b}$ & $10510.65 \mathrm{~b}$ & $0.29 \mathrm{~b}$ \\
\hline
\end{tabular}

As seen in Table 6 there were significant effect for most of the interaction of the cultivation year and seed rate except for thousand kernel weight traits. the highest averages were recorded from using the seed rate of $200 \mathrm{~kg} \mathrm{ha}^{-}$ ${ }^{1}$ in the second season for plant height, spike number $\mathrm{m}^{-2}$, grain number spike ${ }^{-1}$ and grain Yield by $98.28 \mathrm{~cm}, 322.02,40.92$ and 3396.09 respectively. While the highest value gave for biological yield was obtained when the wheat was cultivated at the first season with seed rate of $200 \mathrm{~kg} \mathrm{ha}^{-1}$ by $10917.94 \mathrm{~kg} \mathrm{ha}^{-1}$ and harvest 
index by 0.32 at seed rate $160 \mathrm{~kg} \mathrm{ha}^{-1}$ in the second planting season. On the other side, the cultivation at seed rate of $160 \mathrm{~kg} \mathrm{ha}^{-1}$ in the season 2017-2018 gave the lowest averages compare to most other interaction treatment except the harvest index, which the lowest value was produced from applying seed rate of $200 \mathrm{~kg} \mathrm{ha}^{-1}$ at the first cultivation season by 0.29. the reason of the differences among the averages value It might be due to the apparent variation in the percentage of rain and the period of fall during the months of the plant growing season, which has a great impact on the composition of the seed and its number within the spike and the number of spikes and thus the yield as shown in Table 1. Highest density of the plants per meter square from using $200 \mathrm{~kg} \mathrm{ha}^{-1}$ which introduced more spike number $\mathrm{m}^{-2}$ and more grain in one spike then the total yield although the thousand kernel weight value of this interaction was lower than the other treatments as illustrated in Table 6. These results are in agreement with what (31) and (19) reached to.

Table 6. Effect of cropping season and seeding pattern on wheat grain yield and its components

\begin{tabular}{|c|c|c|c|c|c|c|c|c|}
\hline $\begin{array}{c}\text { Seed } \\
\text { rate } \\
\mathrm{Kg} \mathrm{ha}^{-1}\end{array}$ & $\begin{array}{c}\text { Plant } \\
\text { height }(\mathbf{c m})\end{array}$ & $\begin{array}{c}\text { Spike } \\
\text { number } \\
\mathbf{m}^{-2}\end{array}$ & $\begin{array}{c}\text { Grain } \\
\text { number } \\
\text { spike }^{-1}\end{array}$ & $\begin{array}{c}\text { Thousand } \\
\text { kernel } \\
\text { weight }(\mathrm{g})\end{array}$ & $\begin{array}{c}\text { Grain yield } \\
\left(\mathrm{kg} \mathrm{ha}^{-1}\right)\end{array}$ & $\begin{array}{c}\text { Biological } \\
\text { yield } \\
\left(\mathrm{kg} \mathrm{ha}^{-1}\right)\end{array}$ & $\begin{array}{l}\text { Harvest } \\
\text { index }\end{array}$ & $\begin{array}{c}\text { Seed } \\
\text { rate } \\
\text { Kg ha }^{-1}\end{array}$ \\
\hline 2017- & 200 (S1) & 96.27 ab & 319.23 a & $40.82 \mathrm{a}$ & 40.57 a & 3204.77 b & 10917.94 a & $0.29 \mathrm{~b}$ \\
\hline 2018 & $160(S 2)$ & $94.64 \mathrm{~b}$ & 300.16 c & $38.11 \mathrm{~b}$ & 39.4 a & $2801.9 d$ & 9463.6 b & $0.3 \mathrm{ab}$ \\
\hline 2018- & 200 (S1) & 98.28 a & $322.02 \mathrm{a}$ & $40.92 \mathrm{a}$ & $40.0 \mathrm{a}$ & 3396.09 a & 10843.98 a & $0.31 a b$ \\
\hline 2019 & 160 (S2) & $96.53 \mathrm{ab}$ & $309.55 \mathrm{~b}$ & 38.98 ab & $40.15 a$ & $3023.71 \mathrm{c}$ & $9594.5 \mathrm{~b}$ & 0.32 a \\
\hline
\end{tabular}

The average observes in Table 7 shows that the interaction between the cropping season and seeding pattern had a significant effect on all studied traits. Using the seed drill for planting in the second season had the highest values for plant high, spike number $\mathrm{m}^{-2}$, grains number spike ${ }^{-1}$, grain yield and harvest index by $108.15 \mathrm{~cm}, 346.44$ spike $\mathrm{m}^{-2}, 43.24$ grain per spike, $3772.77 \mathrm{~kg}$ ha-1 and 0.34 respectively compare to the lowest values were obtained from using seed spreader with conventional scattering for plant high by 86.18 $\mathrm{cm}$, spike number per $\mathrm{m}^{2}$ by 284.13 , grain $\mathrm{m}^{-2}$ by 35.62 , grain yield $2568.76 \mathrm{~kg} \mathrm{ha}^{-1}$ and biological yield by $8463.25 \mathrm{~kg} \mathrm{ha}^{-1}$. While the highest value recorded for thousand Kernel Weight was $41.55 \mathrm{~g}$ and for biological yield was $11488.66 \mathrm{~kg} \mathrm{ha}^{-1}$ when the wheat was planted by applying conventional seed spreading in the second cropping and seed drill homogeneity of the distribution of seeds horizontally and vertically on the soil has a great role in equal opportunities for plants to access light and available water, as well as nutrients in the soil, which makes competition less than in the case of random scattering of seeds on the soil, as competition intensifies in dense places, which negatively affects the variation of the outcome of plant height and the total yield of wheat and its components, plant density, grain per spike, spike per $\mathrm{m}^{2}$, thousand Kernel Weight and harvest index (26). what is known about the seed drill is its ability to place the seeds at equal distances, depths and then cover directly, while in the case of random scattering the opposite is occurred, bad feature of heterogeneity of seed distribution has been overcome by following the overlapped scattering of seed distribution lines. in the first season respectively. The

Table 7. Effect of cropping season and seed rate on wheat grain yield and its components

\begin{tabular}{|c|c|c|c|c|c|c|c|c|}
\hline $\begin{array}{l}\text { Seed rate } \\
\mathrm{Kg} \mathrm{ha}^{-1}\end{array}$ & $\begin{array}{c}\text { Plant } \\
\text { height } \\
(\mathrm{cm})\end{array}$ & $\begin{array}{c}\text { Spike } \\
\text { number } \\
\mathbf{m}^{-2}\end{array}$ & $\begin{array}{c}\text { Grain } \\
\text { number } \\
\text { spike }^{-1}\end{array}$ & $\begin{array}{l}\text { Thousand } \\
\text { kernel } \\
\text { weight (g) }\end{array}$ & $\begin{array}{c}\text { Grain } \\
\text { yield (kg } \\
\left.\text { ha }^{-1}\right)\end{array}$ & $\begin{array}{c}\text { Biological } \\
\text { yield } \\
\left(\mathrm{kg} \mathrm{ha}^{-1}\right)\end{array}$ & $\begin{array}{c}\text { Harvest } \\
\text { index }\end{array}$ & $\begin{array}{c}\text { Seed rate } \\
\mathrm{Kg} \mathrm{ha}^{-1}\end{array}$ \\
\hline \multirow{4}{*}{ 2017-2018 } & SD & $104.32 \mathrm{~b}$ & $336.51 \mathrm{~b}$ & $42.96 \mathrm{a}$ & 39.02 a & 3474.7 b & 11488.66 a & $0.3 \mathrm{~b}$ \\
\hline & $\mathbf{C P}$ & $86.18 d$ & $284.13 d$ & $35.62 \mathrm{c}$ & $41.09 d$ & $2568.76 \mathrm{f}$ & $8463.25 d$ & 0.31 b \\
\hline & OP & $95.87 \mathrm{c}$ & $308.44 \mathrm{c}$ & $39.81 \mathrm{~b}$ & 39.83 b & $2966.54 \mathrm{~d}$ & $10620.41 \mathrm{~b}$ & $0.28 \mathrm{c}$ \\
\hline & SD & 108.15 a & 346.44 a & $43.24 \mathrm{a}$ & 38.39 a & 3772.77 a & $11269.4 \mathrm{a}$ & $0.34 \mathrm{a}$ \\
\hline \multirow[t]{2}{*}{ 2017-2018 } & $\mathbf{C P}$ & $86.93 \mathrm{~d}$ & $286.46 \mathrm{~d}$ & $36.73 \mathrm{c}$ & $41.55 c$ & $2757.56 \mathrm{e}$ & 8987.43 c & $0.31 \mathrm{~b}$ \\
\hline & OP & $97.13 \mathrm{c}$ & $314.46 \mathrm{c}$ & $39.89 \mathrm{~b}$ & $40.28 \mathrm{~b}$ & 3099.38 c & $10400.9 \mathrm{~b}$ & $0.3 \mathrm{~b}$ \\
\hline
\end{tabular}


The result in Table 8 shows the variations in studied traits in response to the seed rate and sowing methods interaction. the variations were significant where using the treatment of seed drill with seed rate $200 \mathrm{~kg} \mathrm{ha}^{-1}$ recorded maximum value for plant height, spike number $\mathrm{m}^{-2}$, grains number spike ${ }^{-1}$, grain yield and biological yield by $107.08 \mathrm{~cm}, 355.08$ spikes, 44.67 grains, $3814.56 \mathrm{~kg} \mathrm{ha}^{-1}$ and $11889.45 \mathrm{~kg}$ $\mathrm{ha}^{-1}$ respectively. While, the lowest average was obtained by $85.25 \mathrm{~cm}, 282.64$ spike, 35.77 grain, $2495.68 \mathrm{~kg} \mathrm{ha}^{-1}$ and $7612.38 \mathrm{~kg} \mathrm{ha}^{-1}$ respectively. the highest mean was $42.43 \mathrm{~g}$ for thousand Kernel weight when conventional seed spreading was applied at seed rate $200 \mathrm{~kg}$ ha- 1 and 0.33 for harvest index when seed drill was used with seed rate of $160 \mathrm{~kg} \mathrm{ha}^{-1}$. The lowest value recorded for thousand kernel weight was $37.81 \mathrm{~g}$ from using seed drill

Table 8. Effect of seeding pattern and seeding pattern on wheat grain yield and its components

\begin{tabular}{|c|c|c|c|c|c|c|c|c|}
\hline $\begin{array}{l}\text { Seed rate } \\
\mathrm{Kg} \mathrm{ha}^{-1}\end{array}$ & $\begin{array}{l}\text { Seeding } \\
\text { pattern }\end{array}$ & $\begin{array}{c}\text { Plant } \\
\text { height }(\mathbf{c m})\end{array}$ & $\begin{array}{c}\text { Spike } \\
\text { number } \\
\underset{2}{ }\end{array}$ & $\begin{array}{c}\text { Grain } \\
\text { number } \\
\text { spike }^{-1}\end{array}$ & $\begin{array}{c}\text { Thousand } \\
\text { kernel } \\
\text { weight }(\mathrm{g})\end{array}$ & $\begin{array}{c}\text { Grain } \\
\text { yield }(\mathrm{kg} \\
\left.\text { ha }^{-1}\right)\end{array}$ & $\begin{array}{c}\text { Biological } \\
\text { yield } \\
\left(\mathrm{Kg} \mathrm{ha}^{-1}\right)\end{array}$ & $\begin{array}{c}\text { Harvest } \\
\text { index }\end{array}$ \\
\hline 200 (S1) & $\begin{array}{l}\text { SD } \\
\text { CP } \\
\text { OP }\end{array}$ & $\begin{array}{l}107.08 \text { a } \\
87.87 \mathrm{c} \\
96.87 \mathrm{~b}\end{array}$ & $\begin{array}{l}355.08 \text { a } \\
287.95 \text { d } \\
318.84 \text { b }\end{array}$ & $\begin{array}{l}44.67 \text { a } \\
36.58 d \\
41.37 \mathrm{~b}\end{array}$ & $\begin{array}{l}37.81 \mathrm{~d} \\
42.43 \mathrm{a} \\
40.61 \mathrm{~b}\end{array}$ & $\begin{array}{c}3814.56 \text { a } \\
2830.64 \text { d } \\
3256.1 \mathrm{c}\end{array}$ & $\begin{array}{c}11889.45 \mathrm{a} \\
9838.3 \mathrm{c} \\
10915.13 \mathrm{~b}\end{array}$ & $\begin{array}{c}0.32 \mathrm{a} \\
0.29 \mathrm{bc} \\
0.3 \mathrm{~b}\end{array}$ \\
\hline & SD & 105.38 a & 327.86 b & $41.54 \mathrm{~b}$ & $39.6 \mathrm{c}$ & $3432.91 \mathrm{~b}$ & $10868.61 \mathrm{~b}$ & $0.32 \mathrm{a}$ \\
\hline $160(\mathrm{~S} 2)$ & $\begin{array}{l}\text { CP } \\
\text { OP }\end{array}$ & $\begin{array}{l}85.25 \mathrm{~d} \\
96.13 \mathrm{~b}\end{array}$ & $\begin{array}{l}282.64 d \\
304.06 \mathrm{c}\end{array}$ & $\begin{array}{l}35.77 \mathrm{~d} \\
38.34 \mathrm{c}\end{array}$ & $\begin{array}{l}40.22 \mathrm{~b} \\
39.51 \mathrm{c}\end{array}$ & $\begin{array}{l}2495.68 \text { e } \\
2809.83 \text { d }\end{array}$ & $\begin{array}{c}7612.38 \mathrm{~d} \\
10106.18 \mathrm{c}\end{array}$ & $\begin{array}{l}0.33 \mathrm{a} \\
0.28 \mathrm{c}\end{array}$ \\
\hline
\end{tabular}

Results in Table 9 illustrates the average of the interactions among the cropping season, seed rates and seeding patterns which significantly affected all the traits entered in the study. The interaction between seed rate $200 \mathrm{~kg} \mathrm{ha}^{-1}$ and seed drill sowing in 2018-2019 season recorded highest values for plant high, spike number $\mathrm{m}^{-2}$, grain number spike ${ }^{-1}$ and grain yield were $109.27 \mathrm{~cm}, 356.08$ spike, 44.93 grain and $3921.72 \mathrm{~kg} \mathrm{ha}^{-1}$ respectively. While the lowest averages were obtained from using seed rate of $160 \mathrm{~kg} \mathrm{ha}^{-1}$ by conventional spreading in the first season by $84.77 \mathrm{~cm}$, 282.6 spikes, 34.69 grain, and $2416.44 \mathrm{~kg} \mathrm{ha}^{-1}$ respectively, and $7178.07 \mathrm{~kg} \mathrm{ha}{ }^{-1}$ for biological yield. The highest weight for thousand Kernel was $42.42 \mathrm{~g}$ recorded from a conventional pattern with $200 \mathrm{~kg} \mathrm{ha}^{-1}$ seed rate in the first planting season. The lowest value was $38.91 \mathrm{~g}$ from applying seed drill with 200 $\mathrm{kg} \mathrm{ha}^{-1}$ and the first cultivation season. Lowest biological yield was $7178.07 \mathrm{~kg} \mathrm{ha}^{-1}$ produced from applying conventional method with seed machine with $200 \mathrm{~kg} \mathrm{ha}^{-1}$ seed rate and for harvest index was 0.28 when the overlapped seed spreading was applied. The appropriate seed rate, seeding method and their interactions positively affect the viability and productivity of the plants. They encourage nutrient availability, adequate penetration of sunlight for photosynthesis, and a suitable environment for plants to obtain soil nutrients and efficient use of stored water leading to to increased yield and its components, including spikes plant ${ }^{-1}$ and the number of grains in the spike (25). Sowing wheat by drilling method at seed rates of $150 \mathrm{~kg} \mathrm{ha}^{-1}$ led to a significant increase in plant strength and yield. Increase in yield was associated with the gradual increase in all growth components and biological yield compare to seed broadcasting method. rate $160 \mathrm{~kg} \mathrm{ha}^{-1}$. The uniformity distribution of the seeds in the soil surface by seed drill make the competition between the plants cause to reduce the light and nutrient with an increasing the seed rate of wheat to $175 \mathrm{~kg} \mathrm{ha}^{-1}$ which lead the high of plants close to each other that produce plant higher than that in broadcasted treatment, this result was explained by (25). Also, with increasing wheat seeding rates with homogenous seed distribution, curbing weed growth has increased (35). The highest number of the spike per $\mathrm{m}^{2}$ in the seed drill at the seed rate of $200 \mathrm{~kg} \mathrm{ha}^{-1}$ resulted in the higher amount of the grain yield in the same treatment which might be attributed to the improvement in the number of tillers and directly related to the number spikes unit area ${ }^{-1}$ (14). The tendency of the plant to increase the number of grains was accompanied by a weakness in the formation of a single seed, which affected the weight of the grain especially in the rainy season, which might cause waterlogging at stem elongation 
decreases the kernels number spike $^{-1}$ or reduces kernel weight (8). The grain yield will increase due to increasing spikes $\mathrm{m}^{-2}$ and biological yield (1). The decrease in the

Table 9. Effect of cropping season, seeding pattern and seeding pattern on wheat grain yield and its components

\begin{tabular}{|c|c|c|c|c|c|c|c|c|c|}
\hline Season & $\begin{array}{c}\text { Seed } \\
\text { rate } \\
\mathrm{Kg} \mathrm{ha}_{1}^{-}\end{array}$ & $\begin{array}{l}\text { Seeding } \\
\text { pattern }\end{array}$ & $\begin{array}{c}\text { Plant } \\
\text { height } \\
\text { (cm) }\end{array}$ & $\begin{array}{c}\text { Spike } \\
\text { number } \\
\mathbf{m}^{-2}\end{array}$ & $\begin{array}{c}\text { Grain } \\
\text { number } \\
\text { spike }^{-1}\end{array}$ & $\begin{array}{c}\text { Thousan } \\
\text { d kernel } \\
\text { weight } \\
\text { (g) }\end{array}$ & $\begin{array}{c}\text { Grain } \\
\text { Yield } \\
\left(\mathrm{kg} \mathrm{ha}^{-1}\right)\end{array}$ & $\begin{array}{c}\text { Biological } \\
\text { yield } \\
\left(\mathrm{Kg} \mathrm{ha}^{-1}\right)\end{array}$ & $\begin{array}{c}\text { Harvest } \\
\text { index }\end{array}$ \\
\hline \multirow{6}{*}{$2017-2018$} & \multirow{3}{*}{$\begin{array}{l}200 \\
(\text { S1) }\end{array}$} & SD & 104.90 bc & 354.07 a & $44.4 \mathrm{a}$ & $38.91 \mathrm{e}$ & 3707.4 b & $\begin{array}{c}11983.37 \\
\text { a }\end{array}$ & 0.31 bc \\
\hline & & CP & $87.60 \mathrm{e}$ & 285.66 ef & $36.55 \mathrm{~cd}$ & $42.42 \mathrm{a}$ & $2721.08 \mathrm{~g}$ & $9748.42 \mathrm{~d}$ & $0.28 \mathrm{def}$ \\
\hline & & OP & $96.30 \mathrm{~d}$ & $317.95 \mathrm{c}$ & $41.5 \mathrm{~b}$ & 40.37 bc & $3185.84 \mathrm{~d}$ & $\begin{array}{c}11022.01 \\
\text { b }\end{array}$ & 0.29 cde \\
\hline & \multirow{3}{*}{$\begin{array}{l}160 \\
(\mathrm{~S} 2)\end{array}$} & SD & $103.73 \mathrm{c}$ & 318.94 c & $41.52 \mathrm{~b}$ & $39.13 \mathrm{e}$ & $3242.0 \mathrm{~cd}$ & $\begin{array}{c}10993.94 \\
\text { b }\end{array}$ & 0.29 cde \\
\hline & & CP & 84.77 f & $282.6 \mathrm{f}$ & $34.69 \mathrm{~d}$ & 39.76 cde & $2416.44 i$ & 7178.07 f & 0.34 a \\
\hline & & OP & $95.43 \mathrm{~d}$ & $\begin{array}{c}298.94 \\
\text { ed }\end{array}$ & $38.13 \mathrm{c}$ & $39.3 \mathrm{de}$ & $\begin{array}{c}2747.24 \\
\text { fg }\end{array}$ & $\begin{array}{c}10218.8 \\
\text { cd }\end{array}$ & $0.27 \mathrm{f}$ \\
\hline \multirow{6}{*}{ 2018- 2019} & \multirow{3}{*}{$\begin{array}{l}200 \\
(\mathrm{~S} 1)\end{array}$} & SD & 109.27 a & 356.08 a & $44.93 \mathrm{a}$ & $36.72 \mathrm{f}$ & 3921.72 a & $\begin{array}{c}11795.52 \\
\mathrm{a}\end{array}$ & $0.33 \mathrm{a}$ \\
\hline & & CP & 88.13 e & 290.24 ef & $36.6 \mathrm{~cd}$ & $42.43 \mathrm{a}$ & $2940.2 \mathrm{e}$ & $9928.17 \mathrm{~d}$ & $0.3 \mathrm{bcd}$ \\
\hline & & OP & $97.43 \mathrm{~d}$ & 319 & $41.23 \mathrm{~b}$ & 40.84 & 3326.36 c & $\begin{array}{c}10808.25 \\
\text { bc }\end{array}$ & 0.31 bc \\
\hline & \multirow{3}{*}{$\begin{array}{l}160 \\
\text { (S2) }\end{array}$} & SD & $107.03 \mathrm{ab}$ & 336.79 b & $41.55 \mathrm{~b}$ & $40.07 \mathrm{bcd}$ & $3623.82 \mathrm{~b}$ & $\begin{array}{c}10743.27 \\
\text { bc }\end{array}$ & 0.34 a \\
\hline & & CP & 85.73 ef & 282.68 f & 36.85 c & $40.67 \mathrm{~b}$ & 2574.92 h & 8046.68 e & $0.32 \mathrm{ab}$ \\
\hline & & OP & $96.83 \mathrm{~d}$ & $\begin{array}{c}309.18 \\
\text { cd }\end{array}$ & $38.55 \mathrm{c}$ & 39.71 cde & 2872.41 ef & $9993.55 d$ & 0.29 cde \\
\hline
\end{tabular}

\section{CONCLUSION}

The results obtained from present research it can be safely concluded that wheat sown under drilling at seed rate $200 \mathrm{~kg} \mathrm{ha}^{-1}$ is optimal, had better growth and grain yield components compare to overlapped and conventional spreading pattern by seed distributer machine. the results proved that using overlap pattern is better than conventional scattering of grains, because it was produced better results for the uniformity distribution of grains entire the soil by recording very satisfying $\mathrm{CV} \%$ value which was close to that produced from seed drill. uniform distribution of grain with desire seeds rate provides appropriate environment for seed- soil contact and encourage better establishment for seeds emergence. Furthermore, it provides proper distance for optimum sun light penetration for photosynthesis of plants and for roots uptake of water and soil nutrients resulted in good water use efficiency. The recommendation is applying more seed rate higher than $200 \mathrm{~kg} \mathrm{ha}^{-}$ 1 with different overlap percentages for prose lines. harvest index value results from the high of the yield to the relatively small weight of the same treatment s biological yield.

\section{REFERENCES}

1. Abed, R. D., and Q. M. Kareem. 2018. Screening bread wheat for fertile tillers under fertilization and evaluating of yield and its component for superior under two seeding. The Iraqi Journal of Agricultural Science, 49(3), 336-344

2. Afzalinia, S., M. Shaker, and E. Zare. 2006.'Performance evaluation of common grain drills in Iran', Canadian Biosystems Engineering, 48: 2

3. Akhter, M., A. E. Sabagh, N, Alam, K. Hasan, E. Hafez, C. Barutcular and M. S. Islam. 2017 'Determination of seed rate of wheat (Triticum aestivum L.) varieties with varying seed size', Scientific Journal of Crop Science, 6(3), pp. 161-167

4. ASAE Standards 1999. S341.2. Procedure for Measuring Distribution Uniformity and Calibrating Granular Broadcast Spreaders. $46^{\text {th }}$ Ed. - ASAE, St. Joseph, Mi.

5. Baktash, F. Y. and L. K. Hassan. 2015. Pure line selection from bread wheat for grain yield and it's components under different seeding 
rates. Iraqi Journal of Agricultural Sciences, 46(6): 902-908

6. Carty, MC. and B.Sartain. 2009. How to calibrate your fertilizer spreader. University of Florida IFAS Extensio. ENH62Virin, T., J. Koko

7. Colvin, T. S. and J. H. Turner. 1980. Applying pesticides: Management, application, safety. No. 632.95 COL. CIMMYT

8. Ding, J., P. Liang, P. Wu,M. Zhu, C. Li, X. $\mathrm{Zhu}$, and W. Guo. 2020. Identifying the critical stage near anthesis for waterlogging on wheat yield and its components in the Yangtze River Basin, China. Agronomy, 10(1), 130.

9. El-Sharabasy, M. M. A., M. M. A. Ali, and M. K. Afify. 2007. Manufacturing and evaluation of a selfpropelled machine for broadcasting seeds and granular fertilizers. Misr J. Ag. Engg. 24(4): 752-774

10. Fang, Y., B. C. Xu, N. C. Turner, and F. M. Li. 2010. Grain yield, dry matter accumulation and remobilization, and root respiration in winter wheat as affected by seeding rate and root pruning. European Journal of Agronomy, 33(4), 257-266.

11. Forristal, D., and O. P. Teagasc. 2017. Precise Application of Fertiliser. The Irish Agriculture and Food Development Authority, FAI meeting, Technical Bulletin Series No. 3. - http://www.fertilizerassoc.ie/publications/ technical-bulletins

12. Hassann, M. M., I. M. Khater, and B. Yaşar, 2009. Effect of field size on mechanical wheat seeder performance in reclaimed lands of Egypt, Tarım Makinaları Bilimi Dergisi, 5(1): 45-51.

13. Herbek, J. and C. Lee, 2009. 'A comprehensive guide to wheat management in Kentucky', US Department of Agriculture, M. Scott Smith, Director, Cooperative Extension Service, University of Kentucky College of Agriculture, Lexington, and Kentucky State University, Frankfort

14. Iqbal, J., K. Hayat, S. Hussain, A. Ali, and, M.A.A.H.A Bakhsh.2012. Effect of seeding rates and nitrogen levels on yield and yield components of wheat (Triticum aestivum L.). Pak. J. Nutr, 11, 531

15. Iqtidar, H., M. A. Khan, and H. Khan, 2010. Effect of seed rates on the agro- physiological traits of wheat. Sarhad J. Agric, 26(2): 169-176

16. John, L. S., B. Cornforth, B. Simonson, D. Ogle, and D. Tilley, 2008. 'Calibrating the Truax Rough Rider seed drill for restoration plantings', Tech. Note Plant Materials No. 20. Aberdeen, ID: US Department of Agriculture, Natural Resources Conservation Service, Aberdeen Plant Materials Center. pp: 15

17. Lemus R. 2018. Reduce Seed Cost by Properly Calibrating Your Drill. Mississippi State Univ. Ext. Serv. Pub. No.: P3112.

18. Mahmood, J. W., and M. F. H. Al-Hassan, 2017. Regulation of tillering in wheat and its relationship with grain yield 2 . Contribution percentages of the main stem and primary tillering the number of spike and grain yield. The Iraqi Journal of Agricultural Sciences, 48(2): 528

19. Marti, J., R. Savin, and G. A. Slafer, 2015. Wheat yield as affected by length of exposure to waterlogging during stem elongation. Journal of Agronomy and Crop Science, 201(6): 473-486

20. Mozumder, S., M. Moniruzzaman, S. Rahman, P.Sarker, and S. Faisal,. 2010 'Influence of seed rate and method of sowing on the performance of Bilatidhonia (Eryngium foetidum L.)', Bangladesh Journal of Agricultural Research, 35(2), p: 227-234

21. Nizamani, G. S., S. Tunio, U. A. Buriro, and M. I. Keerio,. 2014. Influence of different seed rates on yield contributing traits in wheat varieties. Journal of Plant Sciences, 2(5), 232236

22. Parish, R. L. 1999. Granular Spreaders: Selection, Calibration, Testing, and Use. Louisiana Agricultural Experiment Station, Louisiana State University Agricultural Center 23. Sanaeifar, A., and M. J. Sheikhdavoodi,. 2012. Evaluating of broadcasting uniformity of centrifugal and oscillating granular broadcasters. Research Journal of Applied Sciences, Engineering and Technology, 4(15), 2460-2468

24. Singh, J., S. Kaur, and H. Majithia,. 2016. Emerging genetic technologies for improving the security of food crops. In Emerging Technologies for Promoting Food Security, Woodhead Publishing. Pp; 23-41.

25. Soomro, U. A., M. U. Rahman, E. A. Odhano, S. Gul, and A. Q. Tareen, 2009. 
Effects of sowing method and seed rate on growth and yield of wheat (Triticum aestivum). World Journal of Agricultural Sciences, 5(2), 159-162

26. Tanveer, S. K., I. Hussain, M. Sohail, N. S. Kissana, and S. G. Abbas, 2003. Effects of different planting methods on yield and yield components of wheat. Asian journal of plant sciences

27. Tanveer, S. K., I. Hussain, M. Asif, M. Y. Mujahid, S. Muhammad, M. Qamar, and M. Asim. 2009. Performance of different wheat varieties/lines as affected by different planting dates and seeding rates under high rainfall area Potohar. Pak. J. Agri. Sci., 46(2):102-106

28. Tilman, D., K. G. Cassman, P. A. Matson, R. Naylor, and S. Polasky,. 2002. Agricultural sustainability and intensive production practices. Nature, 418(6898), 671-677.

29. Tiwari, V. 2007. Grain filling duration as a means for increasing yield in spring wheat. Indian J. Genet., 67(4): 365-368

30. Turan, J., V. Višacki, S. Mehandžić, P. Findura, P. Burg, and A. Sedlar,. 2015. Sowing quality indicators for a seed drill with overpressure. Acta Universitatis Agriculturae et Silviculturae Mendelianae Brunensis, 62(6): 1487-1492
31. Twizerimana, A., E. Niyigaba, I. Mugenzi, W. A. Ngnadong, C. Li, T. Q. Hao, and J. B. Hai, 2020. The Combined effect of different sowing methods and seed rates on the quality features and yield of winter wheat. Agriculture, 10(5), 153

32. UMass Extension 2011: Rotary Spreader

Calibration Procedures. - Center for Agriculture, United States Department of Agriculture, Washington. https://ag.umass.edu/sites/ag.umass. Edu /files /fact-sheets/pdf/rotary spreader calibration.pdf

33. Wang, S., L. Yin, TH. anaka, K. Tanaka, \&and H. Tsujimoto,. 201). Wheat-Aegilops chromosome addition lines showing high iron and zinc contents in grains. Breeding Science, 61(2): 189-195.

34. Wang, X.; X. Hu, Z. Sun, K. Du; G. Song; D. Ren,.2011. Effect of different sowing dates and planting density on group characters and yield of wheat. Chin. Agric. Sci. Bull, 27, 170-176

35. Weiner, J., H. W. Griepentrog. and L. Kristensen,. 2001. 'Suppression of weeds by spring wheat Triticuma estivum increases with crop density and spatial uniformity', Journal of Applied Ecology, 38(4), pp: 784-790. 